\title{
PERAN KOMUNIKASI INTERPERSONAL UNTUK MEWUJUDKAN KESEHATAN MENTAL BAGI KONSELI
}

\author{
Ulin Nihayah \\ Fakultas Dakwah dan Komunikasi UIN Walisongo Semarang \\ Email: ulinnihayah88@gmail.com
}

ABSTRAK

Tealth for human life becomes a very important thing. Health is not
only in the form of physically healthy, but also spiritually healthy
in a mental sense. Diseases caused by mental health can be
handled by interpersonal communication through behavioristik counseling.
Interpersonal communication is to obtain individual information needs
assessment, associated symptoms of mental health problems experienced
by the counselee. Furthermore, the application of behavioristic therapy in
the context of healthy mental growth in individuals with counseling step.

Key: mental health, interpersonal communication, behavior counseling

\section{ABSTRAK}

T

esehatan bagi kehidupan manusia menjadi hal yang sangat penting. Kesehatan tidak hanya dalam bentuk yang sehat secara fisik, tetapi keseh juga sehat rohani dalam arti mental. Penyakit yang disebabkan oleh konseling behavioristik. Komunikasi interpersonal adalahuntuk mendapatkan informasipribadipenilaiankebutuhan, gejala terkaitmasalahkesehatanmental yang dialami oleh konseli. Selanjutnya, penerapan terapi behavioristik dalam kontekspertumbuhanmentalyang sehatpadaindividu dengantahapkonseling.

Key: kesehatan mental, komunikasi interpersonal, konseling perilaku 


\section{PENDAHULUAN}

KESEHATAN merupakan hal yang sangat penting didalam kehidupan manusia. Dengan memiliki kesehatan, manusia bisa melaksanakan seluruh aktifitas dalam kehidupan ke-sehariannya dengan normal. Adapun menurut Undang-Undang Pokok Kesehatan Nomor 9 tahun 1960, dalam pasal 2 dikatakan bahwa yang dimaksud kesehatan adalah yang meliputi kesehatan badan, rohani (mental), dan sosial, dan bukan hanya keadaan yang bebas dari penyakit, cacat, dan kelemahan. Oleh karena itu dalam menjaga kesehatan manusia bukan semata-mata dari luar saja, akan tetapi juga dari dalam jiwa manusia.

Manusia sebagai individu, terkadang dilingkupi oleh masalah yang berkaitan dengan perasaan terkekang, sedih atau takut, yang menyebabkan permasalahan yang lebih serius sehingga menyebabkan ketidaksehatan mental diri individu tersebut dan berdampak pada ketidaksehatan fisik seseorang. Menurut hasil penelitian Elnadi, lebih dari 10\% penyakit di Indonesia, disebabkan oleh gangguan jiwa (Yusuf:2004:5). Selain itu, Kalber juga menyatakan bahwa pada tahun 2020 yang merupakan era semakin berkembangnya modernisasi, depresi yang merupakan salah satu tanda dari ketidaksehatan mental akan menempati urutan ke-2 penyebab disabilitas.(Ghozali Rusyid Affand: 2011: 383)

Dari data diatas, maka jelaslah diperlukan penanganan secara kritis terhadap penanganan masalah individu terkait kesehatan mental. Ketidak sehatan mental individu ini bisa tercermin dari ketidak mampuan seseorang berinteraksi dengan sekitar, dalam konteks sosial bahkan ketidak siapan individu menerima terhadap penerimaan diri. Oleh karena itu salah satu teknik yang dibutuhkan untuk menggali informasi dengan individu yang berkenaan dengan ketidak sehatan mental ini bisa dilakukan dengan komunikasi efektif.

Komunikasi merupakan sebuah media untuk mendekatkan diri antar konselor dan konseli dalam rangka proses bimbingan dan konseling. Dengan terjalinnya komunikasi efektif, konselor bisa mengetahui informasi yang dibutuhkan dalam rangka proses bimbingan konseling. Salah satunya dengan komunikasi yang mendalam(deep interview) terhadap seorang konseli dengan masalah-masalah tertentu. Komunikasi dengan cara tatap muka ini merupakan salah satu jenis komunikasi interpersonal, beberapa teknik komunikasi interpersonal dalam rangka mewujudkan kesehatan mental akan dibahas dalam makalah ini.

\section{PEMBAHASAN}

\section{a. Pengertian Komunikasi Interpersonal}

Istilah komunikasi atau dalam bahasa Inggris, communication berasal dari kata Latin communocatio dan 
bersumber dari kata communis yang berarti sama. Komunikasi Menurut Kamus Besar Bahasa Indonesia (2003) merupakan pengiriman dan penerimaan pesan atau berita antara dua orang atau lebih sehingga pesan yang dimaksud dapat dipahami.

Theodorson (1969) mengungkapkan komunikasi adalah pengalihan informasi dari satu orang atau kelompok kepada orang lain, terutama dengan menggunakan simbol.(Liliweri: 1991) Lebih lanjut lagi menurut Arni Muhammad, Komunikasi dedefinisikan sebagai "Pertukaran pesan verbal maupun non verbal antara si pengirim dengan si penerima pesan untuk mengubah tingkah laku".( Muhammad Arni: 2005: 5) Jadi dari uraian diatas komunikasi merupakan proses pertukaran informasi secara verbal maupun non verbal kepada individu atau organisasi dan menimbulkan efek.

Weaver mengemukakan bahwa komunikasi merupakan seluruh prosedur melalui pikiran seseorang yang dapat mempengaruhi pikiran orang lainnya. Sejalan dengan hal tersebut Barnlund mngatakan, komunikasi timbul didorong oleh kebutuhankebutuhan untuk mengurangirasaketidakpastian, bertindak secara efektif, mem-pertahankan atau memperkuat ego (Marhaeni: 2009: 28). Dari hal ini, bisa dikemukakan bahwa komunikasi yang dilaksanakan dengan interaksi antara dua individu, atau lebih (antar pribadi) bisa saling berpengaruh satu dengan yang lain.
R. Wayne Pace (1979) mengemukakan bahwa komunikasi antarpribadi atau interpersonal communication merupakan proses komunikasi yang berlangsung antara dua orang atau lebih secara tatap muka dimana pengirim dapat menyampaikan pesan secara langsung dan penerima pesan dapat menerima dan menanggapi secara langsung. (Hafied Cangara: 1998:32). Mulyana (2000) menyatakan bahwa "komunikasi interpersonal ini adalah komunikasi yang hanya dua orang, seperti suami istri, dua sejawat, dua sahabat dekat, guru-murid dan sebagainya".(Dedy Mulyana: 2003: 73) Arni (2005) menyatakan bahwa "komunikasi interpersonal adalah proses pertukaran informasi diantara seseorang dengan paling kurang seorang lainnya atau biasanya di antara dua orang yang dapat langsung diketahui balikannya". (Muhammad Arni:2005: 159) Jadi dapat disimpulkan bahwa komunikasi interpersonal merupakan proses komunikasi yang dilakukan oleh dua orang secara pribadi dengan adanya pertukan informasi yang dilakukan oleh komunikan.

Komunikasi interpersonal merupakan bagian dari komunikasi efektif yang dilakukan oleh manusia, sehingga komunikasi ini tidak bersifat statis. Adapun ciri dari komunikasi interpersonal antara lain:

1. Komunikasi interpersonal adalah komunikasi verbal dan non verbal.

2. Komunikasi interpersonal mencakup perilaku tertentu, adapun 
perilaku yang dimaksud antara lain:

- perilaku spontan (spontaneous behaviour) adalah perilaku yang dilakukan karena desakan emosi dan tanpa sensor serta revisi secara kognitif.

- perilaku menurut kebiasaan (script behaviour) adalah perilaku yang di pelajari dari kebiasaan sehari-hari. Perilaku ini khas. Dilakukan pada situasi tertentu dan di mengerti orang. Perilaku ini sering dilakukan tanpa terlalu mempertimbangkan artinya dan terjadi secara spontan karena sudah mendarah daging dalam diri.

- perilaku sadar (contrived behaviour) adalah perilaku yang dipilih karena dianggap sesuai dengan keadaan yang ada. Perilaku ini dipikirkan dan dirancang sebelumnya, dan disesuaikan dengan orang yang akan dihadapi, urusan yang harus diselesaikan, dan situasi serta kondisi yang ada.

3. Komunikasi interpersonal adalah komunikasi yang berproses pengembangan

4. Komunikasi interpersonal mengandungkan umpan balik, interaksi, dan koherensi

5. Komunikasi interpersonal berjalan menurut peraturan tertentu

6. Komunikasi interpersonal me- rupakan kegiatan aktif

7. Komunikasi interpersonal saling mengubah

Pada dasarnya komunikasi interpersonal bersifat aktif, bukan pasif, dalam arti komunikasi dilakukan oleh komunikator atau komunikan dalm hal ini si penerima pesan saja, akan tetapi bersifat dua arah sehigga terdapat umpan balik(feed back) dan efek dari proses komunikasi yang telah dilaksanakan.

Komunikasi interpersonal dirasa sangat penting karena melibatkan individu sebagai pribadi, dengan komunikannya. Adapun fungsi dari komunikasi interpersonal ini diantaranya:

1. Mengenal diri sendiri dan orang lain.

2. Komunikasi antar pribadi memungkinkan kita untuk mengetahui lingkungan kita secara baik.

3. Menciptakan dan memelihara hubungan baik antar personal

4. Mengubah sikap dan perilaku.

5. Bermain dan mencari hiburan dengan berbagai kesenangan pribadi.

6. Membantu orang lain dalam menyelesaikan masalah. (Canggara: 2004:56 )

Dalam rangka mengubah dan mengembangkan potensi individu 
melalui interaksi komunikasi. Terdapat pihak-pihak yang terlibat untuk memberi inspirasi, semangat dan dorongan pada individu untuk merubah pemikiran, perasaan dan bahkan sikap sesuai dengan apa yang menjadi pembahasan bersama.

\begin{tabular}{rrr}
\multicolumn{1}{c}{ Adapun faktor yang } \\
mempengaruhi & komunikasi \\
imterpersonal ini diantaranya: & 1. Self
\end{tabular} concept, sebuah konsep diri, faktor yang paling pentingyangmemengaruhi komunikasi dengan orang lain. 2 . Ability, kemampuan untuk menjadi pendengar yang baik, keterampilan yang mendapat sedikit perhatian 3 . Skill experience, banyak orang merasa sulit untuk melakukan kemampuan untuk mengekspresikan pikiran dan ide-ide. 4. Emotion, yang dimaksud emosi disini adalah individu dapat mengatasi emosinya, dengan cara konstruktif (berusaha memperbaiki kemarahan) 5. Self disclousure, keinginan untuk berkomunikasi kepada orang lain secara bebas dan terus terang. Dengan tujuan untuk menjaga hubungan interpersonal (Millard J. Bienvenu : 1987).

\section{b. Komunikasi Interpersonal Dalam Konseling}

Konseling tidak bisa lepas dari proses komunikasi, termasuk interaksi dan informasi yang dilakukan oleh konselor dan konseli. Cassagrande berpendapat, manusia berkomunikasi karena: a. memerlukan orang lain untuk saling mengisi kekurangan dan membagi kebahagiaan. b. Ingin terlibat dalam proses perubahan. c. Ingin berinteraksi hari ini dan memahami pengalaman masa lalu dan mengantisipasi masa depan. d. Ingin menciptakan hubungan baru(Liliweri, 197:45). Dari beberapa hal diatas dapat dikemukakan bahwa seseorang Konselor memang membutuhkan komunikasi dalam proses bimbingan konseling untuk mengetahui karakteristik pesan atau informasi yang disampaikan pada konseli agar individu memahami arti dan makna pesan yang disampaikan untuk kepentingan dirinya. Sehingga dalam kegiatan bimbingan yang melibatkan interaksi antara konselor dan konseli bisa berjalan dengan baik.

Konseling sendiri merupakan sebuah upaya pemberian bantuan dari seorang konselor kepadaklien, bantuan di sini dalam pengertian sebagai upaya membantu orang lain agar ia mampu tumbuh ke arah yang dipilihnya sendiri, mampu memecahkan masalah yang dihadapinya dan mampu menghadapi krisis-krisis yang dialami dalam kehidupannya(A. Juntika, Nurihsan, Yusuf, Syamsu, 2005: 9)menurut dari ASCA (American School Conselor Assosiation) Konseling dimaknai dengan: hubungan tatap muka yang bersifat rahasia, penuh dengan sikap penerimaan dan pemberian kesempatan dari konselor kepada klien, konselor mempergunakan pengetahuan dan keterampilannya untuk membantu kliennya dalam mengatasi masalahnya. (A. Juntika, Nurihsan, Yusuf, Syamsu: 2005:15) jadi dapat dikemukakan bahwa konseling merupakan proses bantuan dari konselor pada konseli, yang dilakukan secara profesional, dimana 
konselor memberikan bantuan kepada konseli yang sedang mengalami masalah melalui wawancara konseling sehingga konseli dapat mengatasi masalahnya secara mandiri

Menurut Gerald R.Miller (1976) memahami proses komunikasi interpersonal menurut pemahaman hubungan simbiotis antar komunikasi dengan perkembangan relasional, Komunikasi mempengaruhi perkembangan relasional, dan pada gilirannya (secara serentak), perkembangan relasional mempengaruhi sifat komunikasi antara pihak-pihak yang terlibat dalam hubungan tersebut (Miller, 1976:15)

\section{c. Komunikasi interpersonal dan kesehatan mental}

Menurut Dr. Jalaluddin dalam bukunya "Psikologi Agama" bahwa: "Kesehatan mental merupakan suatu kondisi batin yang senantiasa berada dalam kondisi tenang, aman dan tentram, dan upaya untuk menemukan ketenangan batin dapat dilakukan antara lain melalui penyesuaian diri secara resignasi (penyerahan diri sepenuhnya kepada Tuhan) “. (Jalaluddin Rakhmat, 2008: 36)

Mental yang sehat tidak akan mudah terganggu oleh stressor (penyebab terjadinya stres) orang yang memiliki mental sehat berarti mampu menahan diri dari tekanantekanan yang datang dari dirinya sendiri dan lingkungannya. (Noto Soedirdjo, 1980) menyatakan bahwa karakteristik orang yang memiliki kesehatan mental adalah memilki kemampuan diri untuk bertahan dari tekanan-tekanan yang datang dari lingkungannya. Sedangkan menurut Clausen, karentanan (susceptibility) Keberadaan seseorang terhadap stressor berbeda-beda karena faktor genetik, proses belajar dan budaya yang ada dilingkungannya, juga intensitas stressor yang diterima oleh seseorang dengan orang lain juga berbeda.

Dr Breuer dan Sigmund Freud orang mengenal pengobatan hiportela, yaitu pengobatan dengan hypnotis. Kemudian dikenal pula dengan psikoterapi atau auto terapi (penyembuhan diri sendiri) yang dilakukan tanpa menggunakan obat-obatan biasa. Sesuai dengan istilahnya, maka psikoterapi dan autoterapi digunakan dalam untuk menyembuhkan pasien gangguan jiwa (rohani). Usaha dalam mengobati pasien yang menderita penyakit-penyakit tersebut biasanya dihubungkan dengan aspek-aspek keyakinan masing-masing.

Sejumlah kasus yang menunjukkan adanya hubungan antara factor keyakinan dan kesehatan jiwa atau mental tampaknya sudah disadari para ilmuwan beberapa abad yang lalu. misalnya, pernyataan Carel Gustay Jung "diantara pasien saya yang setengah baya, tidak seorang pun yang penyebab penyakit kejiwaannya tidak dilatarbelakangi oleh aspek agama“. Prof. Dr. Muhammad Mahmud Abd Al-Qadir lebih jauh membahas hubungan antara agama dan kesehatan mental melalui pendekatan 
teori biokimia. menurutnya, di dalam tubuh manusia terdapat sembilan kelenjar hormon yang memproduksi persenyawaan-persenyawaan kimia yang memiliki pengarih biokimia tertentu, disalurkan lewat pembuluh darah dan selanjutnya memberi pengaruh kepada eksistensi dan berbagai kegiatan tubuh.

Lebih jauh Muhammad Mahmud Abd Al-Qadir berkesimpulan bahwa segala bentuk gejala emosi seperti bahagia, rasa dendam, rasa marah, takut, berani, pengecut yang ada dalam diri manusia adalah akibat dari pengaruh pembuahan-pembuahan kimia hormon, di samping pembuahan lainnya. tetapi dalam kenyataannya, kehidupan akal dan emosi manusia senantiasa berubah dari waktu ke waktu. Karena itu, selalu terjadi perubahan-perubahan kecil produksi hormon-hormon yang merupakan unsur dasar dari keharmonisan kesadaran dan rasa hati manusia, tepatnya perasaannya. (Ramayulis, 2007: 133)

Solusi terbaik untuk dapat mengatasi masalah-masalah kesehatan mental adalah dengan mengamalkan nilai-nilai agama dalam kehidupan sehari-hari,kesehatanmentalseseorang dapat ditandai dengan kemampuan orang tersebut dalam penyesuaian diri dengan lingkungannya, mampu mengembangkan potensi yang ada dalam dirinya sendiri semaksimal mungkin untuk menggapai ridho Allah SWT, serta dengan mengembangkan seluruh aspek kecerdasan, baik kesehatan spiritual, emosi maupun kecerdasan intelektual.

Hubungan antara kejiwaan dan agama dalam kaitannya dengan hubungan antara agama sebagai keyakinan dan kesehatan jiwa, terletak pada sikap penyerahan diri seorang terhadap suatu kekuasaan Yang Maha Tinggi. Sikap pasrah serupa itu akan memberikan sikap optimis pada seseorang sehingga akan muncul perasaan positip seperti bahagia, rasa senang, puas, merasa sukses, merasa dicintai atau rasa aman.

Agaknya cukup logis kalau setiap ajaran agama mewajibkan pemeluknya untuk melaksanakan ajarannya secara rutin. Bentuk dan pelaksanaan ibadah agama, paling tidak akan ikut berpengaruh dalam menanamkan keluruhan budi yang pada puncaknya akan menimbulkan rasa sukses sebagai pengabdi Tuhan yang setia. Tindak ibadah setidaknya akan memberi rasa bahwa hidup menjadi lebih berarti. Manusia sebagai makhluk yang memiliki kesatuan jasmani dan rohani secara tak terpisahkan membutuhkan perlakuan yang dapat memuaskan keduanya. (Ramayulis, 2007: 136)

Dalam kajiannya, peranan agama dan kesehatan mental ini dibagi menjadi dua yaitu: (Walter Hauston Clark, 1958)

\section{A. Mental yang sehat (healthy mindeddness)}

William James berpendapat bahwa keimanan pada Tuhan adalah terapi terbaik bagi keresahan dan merupakan 
penopang hidup. Seseorang yang sehat mentalnya dalam beragama ini, digambarkan dengan empat hal antara lain:

a) Berfikiran optimis.

Orangyang sehatjiwamenghayati segala bentuk ajaran agama dengan perasaan optimis. Pahala menurut pandangannya adalah sebagai hasil jerih payah yang diberikan Tuhan. Sebaliknya, segala bentuk musibah dan penderitaan yang dianggap sebagai keteledoran dan kesalahan yang dibuatnya dan tidak beranggapan sebagai peringatan Tuhan terhadap dosa manusia.

Sikap optimis dan terbuka yang dimiliki orang yang sehat jasmani ini menyebabkan mereka mudah melupakan kesan-efek buruk dan luka hati yang tergores sebagai ekses agamis tindakannya.

b) Terbuka dan unreflective (tidak termenenung)

c) Biasanya terkait dengan

Pada kenyataanya, dosa yang paling besar ditemukan bukan oleh mereka yang mengalihkan ke luar akan tetapi dalam diri mereka sendiri dan oleh orang-orang yang melihat dari dalam. Akibatnya, pencarian jiwa yang tertutup yang merasakan betapa penting dan lebih mungkin untuk mempertajam implikasinya menjadi sistem teologis dari kekakuan dan kedisiplinan.

Termasuk di dalamnya, seorang yang berpikiran sehat ekstroversi bahwa perbedaan halus dan pemikiran disiplin yang bahan dalam teologi besar akan cenderung absen dari pandangannya. Akibatnya, kesehatan mental akan menjadi lebih tepat mengungkapkan pandangannya walaupun posisi kebebasan baik yang mengadakan tekanan dan kasih sayang dibandingkan murka, dosa dan kebinasaan.

d) Dukungan terhadap tahap pertumbuhan agama

Dukungan terhadap pertumbuhan agama dalam hal ini adalah tidak kaku. Dalam hal ini, agama bukan dianggap bukan sesuatu hal statis akan tetapi selalu dinamis dengan perkembangan masa kini.

B. Mental sakit (suffering)

Dalam hal ini,mental sakit merupakan lawan dari mental sehat dalam agama yaitu penderitaan. Terkait dengan penderitaan ini, penderitaan dapat dibagi 2 :

Faktor dari luar

a) Malapetaka/musibah

Musibah yang serius dapat menggoncangkan kejiwaan seseorang. keguncangan jiwa ini sering menimbulkan kesadaran pada diri manusia, berbagai macam interpretasi untuk mereka waktu sehatnya kurang memiliki pengalaman dan kesadaran agama yang cukup umumnya menafsirkan musibah sebagai peringatan Tuhan kepada dirinya. 
b) Kontemplasi kejahatan

Orang yang menekuni kehidupan dilingkungan dunia hitam, baik sebagai pelaku maupun sebagai pendukung kejahatan umumnya akan mengalami keguncangan batin dan rasa berdosa. perasaan itu mereka tutupi dengan perbuatan yang bersifat kompensatif. Seperti melupakan sejenak minuman keras, berjudi, maupun berfoya-foya. Namun upaya untuk menghilangkan keguncangan batin sering tidak berhasil. Karena itu jiwa mereka menjadi labil dan terkadang dilampiaskan dengan tindakan yang brutal, pemarah, mudah tersinggung, dan berbagai tindakan negatif lainnya.

Faktor intern

\section{Watak}

merupakan salah satu unsur dalam membentuk kepribadian manusia sehingga dapat tercermin dari kehidupan kejiwaan seseorang.

\section{Penyakit saraf}

Orang yang menderita penyakit saraf ini menunjukkan kelainan dalam sikap dan tingkahlakunya. keagamaan dan pengalaman keagamaan yang ditampilkan tergantung dari segi gejala yang mereka derita. misal; para schizoprenia, Paranoia, Psychostenia dan gangguan jiwa lainnya.

3. Konfik dan keraguan

Konflik kejiwaan yang terjadi pada diri seorang mengenai keagamaan mempengaruhi sikap keagamaannya. konflik dan keraguan ini dapat mempengaruhi sikap seseorang terhadap agama seperti taat, fanatik ataupun agnostik sampai ke atheis.

\section{Jauh dari Tuhan}

Orang yang dalam kehidupannya jauh dari ajaran agama, lazimnya akan merasa dirinya lemah dan kehilangan pegangan saat menghadapi cobaan. hal ini menyebabkan terjadi semacam perubahan sikap keagamaan pada diri seseorang.

Dalam Islam sendiri, sehat atau tidaknya seseorang berpijak pada aspek spiritualitas keagamaannya. Seberapa jauh keimanan seseorang yang tercermin dalam kehidupan keberagaman dalam keseharian menjadi titik tolak penting dalam menentukan sehat atau tidaknya mental seseorang.

Dalam Al-Qur'an, dijelaskan bahwa terdapat beberapa ayat terkait dengan kesehatan mental, meliputi hubungan manusia, lingkungan dan Tuhan, yang kesemuanya ditujukan untuk mendapatkan hidup bermakna dunia akhirat. Contoh-contoh ayatnya sebagai berikut:

a. Yang berkaitan dengan hubungan manusia dan dirinya sendiri ( $h a b l$ min al-nafs). Dalam hubungan manusia mengembangkan potensinya dalam bentuk amr ma'ruf wa nahi munkar

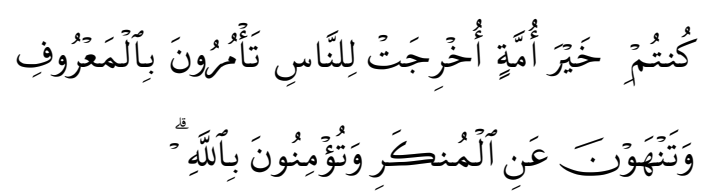


"Kamu adalah umat yang terbaik yang dilahirkan untuk manusia, menyuruh kepada yang ma'ruf, dan mencegah dari yang munkar, dan beriman kepada Allah."(Q.s Ali Imran:110)

b. Yang berkaitan dengan hubungan manusia dengan manusia (habl min an-nas), manusia mengembangkan dan memanfaatkan potensinya dalam bentuk menjalin persaudaraan atau malah sebaliknya.

Firman Allah SWT:

Muhammad itu adalah utusan Allah dan orang-orang yang bersama dengan Dia adalah keras terhadap orang-orang kafir, tetapi berkasih sayang sesama mereka. kamu Lihat mereka ruku'dan sujud mencari karunia Allah dan keridhaanNya, tanda-tanda mereka tampak pada muka mereka dari bekas sujud (Q.S Al-Fath:29)

c. Ayat-ayat yang berkaitan dengan Habl min al'alam, dimana manusia mempunyai kecenderungan untuk mengembangkan dan memanfaatkan potensinya dalam bentuk kelestarian dan memanfaatkan alam seisinya atau sebaliknya, merusak, misalnya:

Firman Allah SWT:

Apabila telah ditunaikan shalat, Maka bertebaranlah kamu di muka bumi; dan carilah karunia Allah dan ingatlah Allah banyak-banyak supaya kamu beruntung. (Qs. Al-jumu'ah: 10)

d. Sedangkan yang berkaitan dengan habl min Allah, manusia mempunyai kecenderungan untuk mengembangkan dan memanfaatkan potensinya dalam bentuk beribadah kepada Allah atau sebaliknya mengingkariNya. Misalnya:

Firman Allah:

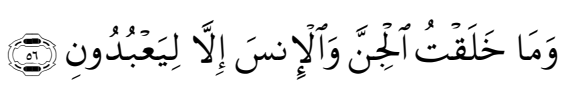

Artinya: Dan aku tidak menciptakan jin dan manusia melainkan supaya mereka mengabdi kepada-Ku.(Q.S Adzariyat: 56)

Disisi lain, gangguan mental dalam Islam sendiri terdapat aspekaspek yang berkaitan dengan penyimpangan-penyimpangan sikap batin. Ada dua aspek dalam gejala gangguan mental ini yaitu qolb dan af'al (hati dan perbuatan). Gangguan mental ini dapat dijabarkan sebagai berikut:

a. Hati yang menyimpang dari keikhlasan dan ketundukan kepada Allah sehingga menjadi lupa terhadap posisinya sebagai hamba Allah. Wujud dari penyimpangan ini bias dalam bentuk riya', hasad, ujub, takabur, tamak dan sebagainya.

b. Perilaku yang terbiasa dengan pelanggaran ajaran agama 
di sebabkan oleh dominan peran nafs al-ammarah dalam kehidupan. Pada kondisi ini ada dua bentuk gangguan mental yaitu: 1) kekuatan fitrah untuk mendengarkan dan melihat kebenaran, serta berpihak dan menyukai kebenaran tidak berfungsi lagi dengan baik. Hati orang seperti ini tertutup dari seruan-seruan kebenaran. 2) memandang indah dan baik perbuatan-perbuatan dosa dan kesesatan sehingga tetap merasa nikmat untuk melakukannya.

Dalam praktiknya, komunikasi interpersonal dalam menumbuhkan kesehtan mental bisa dilakukan dengan konseling behavioristik. Pendekatan behavioral merupakan pandangan ilmiah tentang tingkahlaku manusia. Pandangan ini melihat individu sebagai produk dari kondisioning sosial, dan sedikit sekali melihat potensi individu sebagai prosedur lingkungan. Pada awal pendekatan ini hanya mempercayai hal yang dapat diamati dan diukur sebagaisesuatu yang sah dalam pengukuran kepribadian (radical behaviorism), dan dikembangkan lebih lanjut yang mulaimenerimafenomenayangabstrak seperti id, ego, super ego dan ilusi. Pendekatan ini memandang perilaku yang malajustru sebagai hasil belajar dari lingkungan. Dengan Konseling behavioristik, klien dibantu untuk belajar cara bertindak yang baru dan pantas, atau membantu mereka untuk memodifikasi atau mengeliminasi tingkah laku yang berlebih. Dengan perkataan lain, membantu klien agar tingkah lakunya menjadi lebih adaptif dan menghilangkan yang maladaftif

Menurut chaplin behavioral/ behaviorisme adalah satu pandangan teoritis yang beranggapan, bahwa persoalan psikologi adalah tingkah laku, tanpa mengaitkan konsepsikonsepsi mengenai kesadaran dan mentalitas (J.P Chaplin, 2006 :54)

Dari pengertian konseling dan behaviorisme yang dipaparkan di atas kita dapat menarik kesimpulan bahwa yang dimaksud dengan konseling behavioral adalah sebuah proses konseling (bantuan) yang diberikan oleh konselor kepada klien dengan menggunakan pendekatan-pendekatan tingkah laku (behavioral), dalam hal pemecahan masalah-masalh yang dihadapi serta dalam penentuan arah kehidupan yang ingin dicapai oleh diri klien.

Menurut Krumboltz \& Thoresen (Surya, 1988:187)konselingbehavioral adalah suatu proses membantu orang untuk belajar memecahkan masalah interpersonal, emosional, dan keputusan tertentu. Jika kita perhatikan lebih lanjut, pendekatan dalam konseling behavioral lebih cenderung direktif, karena dalam pelaksanaannya konselor-lah yang lebih banyak berperan. Adapun Peran Konselor dalam konseling behavioristik diantaranya:

a. Menyebutkan tingkah laku maladaptip

b. Memilih tujuan-tujuan yang masuk akal 
c. Mengarahkan dan membimbing keluarga untuk merubah tingkah laku yang tak sesuai

Penerapan teori tingkah laku ke dalam konseling pada konseli menekankan 3 hal pokok:

a. Menciptakan konseling yang positif

b. Mendiagnosis problem-problem yang dialami oleh konseli ke dalam istilah tingkah laku

c. Mengimplementasikan prinsiprinsip tingkah laku dari penguat dan model

d. Penggunaan model dan permainan peranan dalam proses penyembuhan.

Keseluruhan proses konseling behavioristik yang dilaksanakan tidak akan bisa berlangsung apabila tidak dilaksanakan komunikasi efektif dengan cara interpersonal. Karena bentuk dari konseling behavioristik ini menggali informasi pada individu secara menyeluruh secara pribadi. Adapun tahapan komunikasi interpersonal dalam konseling ini diantaranya:

\section{a. Asesmen}

Hal-hal yang digali dalam asesmen meliputi analisis tingkah laku bermasalah yang dialami konseli saat ini; analisis situasi yang di dalamnya masalah konseli terjadi; analisis motivasional; analisis self-control; analisis hubungan sosial; dan analisis lingkungan fisik-sosial budaya.

\section{b. Menentukan Tujuan}

Tujuan memiliki tempat sentral dalam terapi Behavior, karena tujuan inilah yang akan menghasilkan kontrak yang memandu jalannya terapi. Tujuan yang ditetapkan akan digunkan sebagai tolak ukur untuk melihat keberhasilan proses terapi. Proses terapi akan dihentikan jika telah mencapai tujuan.

Konselor dan konseli mnetapkan tujuan pada awal terapi. Tujuan terapi harus jelas, konkret, dipahami, dan disepakati oleh klien dan konselor. Konselor dan klien mendiskusikan perilaku yang terkait dengan tujuan, keadaan yang diperlukan untuk perubahan, sifat tujuan, dan rencana tindakan untuk bekerja ke arah tujuan ini.

\section{c. Mengimplementasikan Teknik}

Setelah merumuskan tujuan yang ingin dicapai, konselor dan konseli menentukan strategi belajar yang terbaik untuk membantu konseli mencapai perubahan tingkah laku yang diinginkan. Konselor dan konseli mengimplementasikan teknik-teknik konseling sesuai dengan masalah yang dialami oleh konseli.

\section{d. Mengakhiri Konseling}

Proses konseling akan berakhir jika tujuan yang ditetapkan di awal konseling telah tercapai. Meskipun demikian, konseli tetap memiliki tugas, yaitu terus melaksanakan perilaku baru yang diperolehnya selama proses konseling, di dalam kehidupannya sehari-hari. 


\section{PENUTUP}

Komunikasi dalam proses konseling sangat diperlukan terutama pada saat pelaksanaan deep interview (wawancara mendalam) pada konseli dalam rangka menumbuhkan kesehatan mental. Lebih lanjut lagi proses sugesti yang dilakukan dalam rangka penguatan kesehatan mental bagi konseli sehingga konseli bisa memecahkan masalahnya secara mandiri

Komunikasi interpersonal yang dilakukan pada proses konseling behavioristik, dilaksanakan oleh konselor dan konseli dengan membuat need assessment sehingga konselor bisa menganalisis apa yang dialami individu, bagaimana bentuk konseling behavioristik yang tepat dan bagaimana tujuan tersebut dapat dilakukan secara optimal.

\section{DAFTAR PUSTAKA}

A. Juntika, Nurihsan, Yusuf, Syamsu, Landasan Bimbingan dan Konseling, Bandung: PT. Remaja Rosdakarya,2005

Cangara, Hafied, Pengantar Ilmu Komunikasi, (Jakarta, PT. Raja Grafindo Persada, 1998)

Chaplin, Kamus Lengkap Psikologi. Jakarta: PT. RajaGrafindo Persada. (2006)
Fajar, Marhaeni, Ilmu Komunikasi Teori \& Praktek Edisi Pertama, Graha Ilmu, Yogyakarta, 2009

Ghozali Rusyid Affand, Religiusitas Sebagai Prediktor Terhadap Kesehatan Mental Studi Terhadap Pemeluk Agama Islam, Jurnal Psikologi UMM Volume 6, No.1, April 2011

Liliweri, Alo. 1991. Komunikasi Antarpribadi. Bandung : Citra Aditya Bakti

Mulyana, Dedy. (2003). Ilmu Komunikasi Suatu Pengantar. Bandung: Rosda karya.

Miller, Gerald R. (Editor). 1976. Exporation in Interpersonl Communication Vol. V. Baverly Hills-London: Sage Publications.

Rakhmat, Jalaluddin, Psikologi Komunikasi,Bandung, Remaja Rosdakarya.2008

Yusuf, Syamsu Mental Higiene. Bandung: Pustaka Bani Quaraisy 2004.

Walter Hauston Clark, Psichology of religion, 